\title{
Analisis Genetik Arsitektur Malai Padi Menggunakan Dua Populasi F2
}

\author{
Genetic Analysis of Panicle Architecture Using Two F2 Population in Rice
}

\author{
Fitrah Ramadhan $^{1}$, Willy Bayuardi Suwarno ${ }^{2}$, Anggi Nindita ${ }^{2}$, dan Hajrial Aswidinnoor ${ }^{2 *}$
}

${ }^{1}$ Program Studi Pemuliaan dan Bioteknologi Tanaman, Sekolah Pascasarjana, Institut Pertanian Bogor

${ }^{2}$ Departemen Agronomi dan Hortikultura, Fakultas Pertanian, Institut Pertanian Bogor

(Bogor Agricultural University), Jl. Meranti, Kampus IPB Darmaga, Bogor 16680, Indonesia

Diterima 3 Agustus 2017/Disetujui 13 Februari 2018

\begin{abstract}
Improvement of rice panicle architecture is one important objective in the development of improved new-plant-type rice varieties. Panicle architecture is directly related to yield components in rice. The aims of this study were to obtain information on inheritance pattern of panicle architecture on F2 generation and to obtain the best selected individuals. The experiment was conducted at Sawah Baru Experimental Farm Bogor, from May to October 2016. Two F2 populations derived from crosses of IPB 3S/IPB160-F-36, IPB160-F-36/IPB 5R and three genotypes of parents were used as experimental materials. A total of 208 and 204 plant samples were taken representing each of the two F2 populations and 20 plants representing the parents. Three panicles were taken randomly from each individual as observed samples. The results showed that additive gene action influenced number of primary branches in population of IPB 3S/IPB160-F-36, whereas in the population of IPB160-F-36/IPB 5R, most of the panicle architecture traits were controlled by additive gene action except for the length of primary branches. All of panicle architecture traits were controlled by relatively many genes except length of primary branches and number of grains on primary branches in the IPB 3S/IPB160-F-36 population. The panicle architecture of the two observed population was genetically varies. The heritability estimates were moderate to high. Selection could increase the mean of panicle architecture traits using either single or multiple traits simultaneously.
\end{abstract}

Keywords: gene action, heritability, genetic variability, panicle traits

\section{ABSTRAK}

Pengembangan padi tipe baru dilakukan salah satunya melalui rekayasa arsitektur malai tanaman padi. Arsitektur malai merupakan karakter-karakter yang berkaitan langsung dengan komponen hasil tanaman padi. Penelitian ini bertujuan untuk mempelajari pola pewarisan karakter arsitektur malai pada generasi F2 dan mendapatkan individu-individu terbaik hasil seleksi. Penelitian dilakukan di Kebun Percobaan Sawah Baru, Kabupaten Bogor, dari Mei sampai Oktober 2016. Dua populasi zuriat hasil persilangan IPB 3S/IPB160-F-36, IPB160-F-36/IPB 5R dan tiga genotipe tetua digunakan sebagai materi percobaan. Total sebanyak 208 dan 204 tanaman berturut-turut mewakili populasi F2 dan 20 tanaman mewakili setiap genotipe tetua. Setiap individu diambil sebanyak tiga malai untuk diamati. Hasil penelitian menunjukkan bahwa aksi gen aditif mempengaruhi karakter jumlah cabang primer pada populasi zuriat persilangan IPB 3S/IPB160-F-36, sedangkan pada populasi zuriat IPB160-F-36/IPB 5R hampir seluruh karakter arsitektur malai dikendalikan oleh aksi gen aditif kecuali panjang cabang primer. Seluruh karakter arsitektur malai melibatkan banyak gen kecuali karakter panjang cabang primer dan jumlah gabah per cabang primer pada populasi IPB 3S/IPB160-F-36. Terdapat keragaman genetik pada karakter arsitektur malai dua populasi yang diuji. Heritabilitas arti luas karakter yang diamati tergolong sedang sampai tinggi. Seleksi dapat meningkatkan nilai tengah karakter arsitektur malai baik menggunakan karakter tunggal maupun secara simultan.

Kata kunci: aksi gen, heritabilitas, karakter malai, keragaman genetik

\section{PENDAHULUAN}

Beras merupakan makanan pokok utama yang perannya belum dapat digantikan oleh tanaman pokok lain di

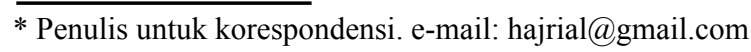

Indonesia. Beras dapat mempengaruhi pola perekonomian, politik bahkan kehidupan bermasyarakat suatu daerah. Sebagai komoditas yang strategis, tuntutan peningkatan dan kestabilan produksi beras terus diupayakan dengan berbagai cara salah satunya melalui program pemuliaan tanaman padi. 
Perakitan varietas tanaman unggul saat ini salah satunya diarahkan untuk perakitan varietas padi tipe baru (PTB) melalui perbaikan arsitektur tanaman. Padi tipe baru menghasilkan produksi yang lebih banyak 10-30\% dari varietas unggul seperti IR64 dan Ciherang dicirikan dengan jumlah gabah per malai yang banyak, batang yang kokoh, daun yang lebih lebar dan tebal, umur genjah, jumlah anakan yang sedikit dan tanaman yang lebih tinggi (Abdullah et al., 2008). Salah satu aspek penting dalam peningkatan produksi padi tipe baru adalah arsitektur malai.

Terdapat 5 karakter malai yang sangat mempengaruhi produksi tanaman padi yaitu panjang malai, jumlah cabang primer, panjang gabah, ketebalan gabah dan rasio panjang/ tebal gabah (Zhang et al., 2015). Selain itu, karakter percabangan, panjang aksis, dan jumlah gabah juga merupakan 3 karakter penting dari arsitektur malai (Adriani et al., 2016). Ketiga karakter tersebut disederhanakan menjadi sebuah karakter kompleks yang sangat menentukan komponen hasil tanaman padi yang disebut dengan kerapatan gabah (panicle density) (Futsuhara et al., 1980; Ikeda et al., 2010). Namun demikian, karakter komponen hasil tanaman padi dikendalikan oleh banyak gen dimana sangat dipengaruhi oleh lingkungan (Huang et al., 2010; Ikeda et al., 2013). Distribusi dan jumlah gen yang mengatur karakter tersebut belum sepenuhnya diketahui dan merupakan tantangan bagi pemulia dalam perakitan varietas padi berdaya hasil tinggi.

Strategi awal yang penting dilakukan dalam memperbaiki suatu karakter yang diinginkan adalah dengan mempelajari pola pewarisan karakter tersebut. Salah satunya adalah melalui persilangan dua individu tanaman yang memiliki karakter yang berbeda. Populasi hasil persilangan ini disebut populasi bersegregasi. Populasi bersegregasi merupakan populasi yang terdiri atas individu-individu yang beragam secara genetik dan masih bersegregasi pada generasi selanjutnya. Perbedaan genetik pada populasi bersegregasi dapat dievaluasi secara morfologi maupun melalui penanda molekuler (Prabakaran et al., 2010). Selanjutnya, perlu dilakukan seleksi terhadap karakter yang diinginkan. Keragaman genetik dan heritabilitas sangat berpengaruh terhadap keberhasilan suatu proses seleksi (Poehlman dan Sleper, 1996; Ogunniyan dan Olakojo, 2014). Penelitian ini bertujuan untuk mempelajari pola pewarisan karakter arsitektur malai padi pada populasi F2 dan mendapatkan individu-individu terbaik hasil seleksi.

\section{BAHAN DAN METODE}

Penelitian ini dilakukan pada bulan Mei sampai dengan Oktober 2016 di Kebun Percobaan Sawah Baru Kecamatan Darmaga, Kabupaten Bogor, Jawa Barat. Pengamatan pasca panen dilakukan di Laboratorium Pemuliaan Tanaman Departemen Agronomi dan Hortikultura, Institut Pertanian Bogor. Bahan genetik yang digunakan adalah zuriat F2 hasil persilangan IPB 3S/IPB160-F-36 dan IPB160-F-36/IPB 5R masing-masing sebanyak 208 dan 204 tanaman dan tetua IPB160-F-36, IPB 3S dan IPB 5R masing-masing sebanyak 20 tanaman. Tetua IPB160-F-36 memiliki kerapatan gabah yang tinggi, sedangkan tetua IPB $3 \mathrm{~S}$ dan $5 \mathrm{R}$ memiliki malai dan percabangan malai yang panjang. Pertanaman dipupuk dengan menggunakan urea sebanyak $150 \mathrm{~kg} \mathrm{ha}^{-1}$ dan NPK (15:15:15) sebanyak $250 \mathrm{~kg} \mathrm{ha}^{-1}$.

Pengamatan fenotipik dilakukan terhadap 3 sampel malai yang diambil dari masing-masing individu populasi F2 dan tetua. Karakter arsitektur malai yang diamati meliputi panjang malai, jumlah cabang primer, panjang cabang primer, jumlah gabah per cabang primer dan kerapatan gabah (grain density). Kerapatan gabah dihitung berdasarkan perbandingan jumlah gabah per malai dengan total panjang cabang primer dan axis (Ikeda et al., 2010). Selanjutnya, data yang diperoleh dianalisis menggunakan program statistik Microsoft Excel, Minitab 17 dan STAR 2.0.1. IRRI.

\section{Analisis Skewness dan Kurtosis}

Pendugaan aksi gen dan jumlah gen dilakukan dengan menggunakan analisis skewness dan kurtosis untuk setiap karakter yang diamati pada generasi F2 (Jayaramachandran et al., 2010; Samak et al., 2011; Jambormias, 2014). Persamaan Skewness dan Kurtosis menurut Roy (2000) sebagai berikut :

$$
\begin{gathered}
\text { Skewness }=\frac{\sum_{i=1}^{N}(Y i-\bar{Y})^{3}}{(N-1) S^{3}} \\
\text { Kurtosis }=\frac{\sum_{i=1}^{N}(Y i-\bar{Y})^{4}}{(N-1) S^{4}}
\end{gathered}
$$

dimana $\mathrm{Yi}=$ nilai genotipe $\mathrm{ke}-\mathrm{i}, \overline{\mathrm{Y}}=$ rata-rata, $\mathrm{S}=$ standar deviasi, $\mathrm{N}=$ jumlah genotipe yang diamati. Nilai skewness dan kurtosis diuji menggunakan galat baku uji skewness dan kurtosis dengan statistik uji :

$$
Z_{S}=\frac{S}{S E_{S}} \quad Z_{K}=\frac{S}{S E_{K}}
$$

dimana $\mathrm{S}=$ skewness, $\mathrm{K}=$ kurtosis, $\mathrm{SE}_{\mathrm{S}}=$ galat baku skewness, $\mathrm{SE}_{\mathrm{K}}=$ galat baku kurtosis, dengan nilai uji kritis dua arah untuk $\mathrm{Z}_{\mathrm{S}}$ dan $\mathrm{Z}_{\mathrm{K}}$ adalah $\mathrm{Z}_{0.05 / 2}=1.96$ dan $\mathrm{Z}_{0.01 / 2}=$ 2.75 .

Skewness menunjukkan pengaruh epistatis dari suatu karakter. Jika skewness $=0$ menunjukkan tidak adanya pengaruh epistatis, skewness $>0$ menunjukkan adanya aksi gen epistatis komplementer, dan skewness $<0$ karakter dikendalikan oleh aksi gen epistatis duplikat. Kurtosis mengindikasikan jumlah gen yang mengendalikan suatu karakter. Jika nilai kurtosis $>3$ dan bernilai positif maka karakter tersebut dikendalikan oleh sedikit gen, sedangkan jika nilai kurtosis $<3$ dan bernilai negatif maka karakter tersebut dikendalikan oleh banyak gen. Interpretasi nilai duga skewness dan kurtosis merujuk skema Jambormias (2014).

\section{Pendugaan Komponen Ragam dan Heritabilitas}

Data yang diperoleh dianalisis untuk menduga komponen ragam masing-masing karakter meliputi ragam fenotip, ragam lingkungan, ragam genetik dan heritabilitas. Nilai heritabilitas diduga menggunakan persamaan:

$$
\mathrm{h}_{\mathrm{bs}}^{2}=\frac{\sigma_{g}^{2}}{\sigma_{p}^{2}}
$$


Menurut Stansfield (1991), nilai heritabilitas diklasifikasikan sebagai berikut: $\mathrm{h}^{2}<20 \%=$ rendah, $20 \% \geq$ $\mathrm{h}^{2}<50 \%=$ sedang dan $\mathrm{h}^{2} \geq 50 \%=$ tinggi.

\section{Kemajuan Seleksi}

Nilai kemajuan genetik dapat diduga menggunakan persamaan berikut :

$$
\begin{aligned}
\mathrm{G} & =\mathrm{S} \mathrm{h}_{\mathrm{bs}}^{2} \\
\mathrm{G}(\%) & =\frac{G}{\overline{X_{0}}} \times 100 \%
\end{aligned}
$$

dimana $\mathrm{S}=$ differensial seleksi, $\mathrm{G}=$ kemajuan seleksi, $\mathrm{G}$ $(\%)=$ kemajuan genetik dalam persen, $\mathrm{h}_{\mathrm{bs}}^{2}=$ heritabilitas arti luas, $X_{0}=$ rata-rata populasi awal.

Seleksi simultan dilakukan berdasarkan skoring terhadap individu-individu terpilih dari seluruh karakter tunggal dengan intensitas seleksi 10\%. Individu-individu dengan skor terpilih tertinggi dari setiap karakter dipilih sebagai grup individu hasil seleksi secara simultan.

\section{HASIL DAN PEMBAHASAN}

\section{Analisis Skewness dan Kurtosis}

Analisis skewness dan kurtosis masing-masing dapat memberikan informasi tentang sifat dasar aksi gen dan jumlah gen yang mengendalikan suatu karakter (Samak et al., 2011). Analisis skewness dan kurtosis memainkan peranan penting untuk menentukan ada tidaknya epistatis pada zuriat persilangan. Nilai epistatis biasanya sangat kecil sehingga dapat diabaikan, namun jika terdeteksi adanya aksi gen epistatis maka akan berpengaruh terhadap fenotipe tanaman. Pengaruh aksi gen epistatis dan dominan akan berkurang pada setiap generasi sebaliknya proporsi gen aditif bertambah (Roy, 2000). Kurtosis negatif (platikurtik) atau positif (leptokurtik) masing-masing mengindikasikan banyak gen aditif atau sedikitnya gen yang terlibat dalam mengendalikan suatu karakter. Skewness negatif dan positif berturut-turut mengindikasikan terjadinya epistatis duplikat dan epistatis komplementer (Jayaramachandran et al., 2010; Roy, 2000).

Nilai skewness dan kurtosis zuriat persilangan IPB 3S/IPB160-F-36 (186) dan IPB160-F-36/IPB 5R (188) untuk karakter arsitektur malai dapat dilihat pada Tabel 1. Menurut Lestari et al. (2015) jika sebaran genotipe suatu karakter menyebar tidak normal dan memiliki kemenjuluran (skewness) maka diduga karakter tersebut dipengaruhi oleh adanya aksi gen non aditif. Hal ini terlihat pada zuriat persilangan IPB 3S/IPB160-F-36 dimana semua karakter arsitektur malai menunjukkan adanya skewness sehingga dikendalikan oleh aksi gen non aditif kecuali karakter jumlah cabang primer. Karakter jumlah cabang primer tidak memperlihatkan skewness sehingga diduga dikendalikan oleh aksi gen aditif. Adanya aksi gen aditif pada karakter jumlah cabang primer ini secara konsisten dijumpai pada dua populasi zuriat persilangan IPB 3S/IPB160-F-36 dan IPB160-F-36 x IPB 5R; yang mengindikasikan bahwa karakter tersebut merupakan karakter yang stabil. Hal ini sesuai dengan laporan Mahmood et al. (2004) dan Saleem et al. (2005) bahwa adanya pengaruh aksi gen aditif yang mengendalikan karakter jumlah cabang primer. Selanjutnya Saleem et al. (2005) juga melaporkan adanya pengaruh aksi gen aditif pada karakter panjang malai dan kerapatan gabah. Anyanwu dan Obi (2015) melaporkan adanya pengaruh aksi gen dominan dalam pewarisan sifat karakter jumlah gabah per cabang primer pada F2 tanaman padi. Lestari et al. (2015) juga melaporkan bahwa panjang malai secara konsisten dikendalikan oleh aksi aditif pada dua populasi persilangan tanaman padi. Karakter-karakter yang dikendalikan oleh aksi gen aditif mengindikasikan seleksi dapat berlangsung pada generasi awal karena karakter tersebut dapat diwariskan

Tabel 1. Pendugaan aksi gen dan jumlah gen karakter malai zuriat persilangan IPB 3S/IPB160-F-36 dan IPB160-F-36/IPB $5 \mathrm{R}$

\begin{tabular}{lcccccc}
\hline Karakter & Populasi & Normalitas & Skewness & Kurtosis & Aksi gen & $\begin{array}{c}\text { Jumlah gen } \\
\text { pengendali }\end{array}$ \\
\hline \multirow{2}{*}{ Panjang malai } & IPB3S/IPB160-F-36 & 0.23 & $0.35 *$ & $0.59 \mathrm{tn}$ & Dm & Banyak \\
& IPB160-F-36/IPB5R & 0.01 & $-0.15 \mathrm{tn}$ & $-0.36 \mathrm{tn}$ & Ad & Banyak \\
Jumlah cabang primer & IPB3S/IPB160-F-36 & 0.00 & $0.03 \mathrm{tn}$ & $-0.01 \mathrm{tn}$ & Ad & Banyak \\
& IPB160-F-36/IPB5R & 0.01 & $-0.20 \mathrm{tn}$ & $0.51 \mathrm{tn}$ & Ad & Banyak \\
Panjang cabang primer & IPB3S/IPB160-F-36 & 0.00 & $0.57 * *$ & $1.41 * *$ & EK & Sedikit \\
& IPB160-F-36/IPB5R & 0.04 & $-0.10 \mathrm{tn}$ & $-0.72 *$ & EA & Banyak \\
Jumlah gabah/cabang primer & IPB3S/IPB160-F-36 & 0.00 & $0.73 * *$ & $1.40^{* *}$ & EK & Sedikit \\
& IPB160-F-36/IPB5R & 0.92 & $0.04 \mathrm{tn}$ & $-0.37 \mathrm{tn}$ & Ad & Banyak \\
Kerapatan gabah & IPB3S/IPB160-F-36 & 0.03 & $0.52 * *$ & $0.36 \mathrm{tn}$ & Dm & Banyak \\
& IPB160-F-36/IPB5R & 0.62 & $0.27 \mathrm{tn}$ & $0.10 \mathrm{tn}$ & Ad & Banyak \\
\hline
\end{tabular}

Keterangan: $\mathrm{Ad}=$ aditif, $\mathrm{Dm}=$ Dominan, $\mathrm{EK}=$ Epistatis komplementer, $\mathrm{EA}=$ epistatis aditif. Nilai $\mathrm{P}<0.05$ menunjukkan terjadinya pelanggaran asumsi kenormalan, $\mathrm{tn},{ }^{*}, * *=$ berturut-turut hasil uji $\mathrm{F}$ tidak nyata pada taraf $5 \%$, nyata pada taraf $5 \%$, dan nyata pada taraf $1 \%$ 
pada generasi berikutnya. Sebaliknya, karakter-karakter yang dikendalikan oleh aksi gen dominan atau epistatis maka seleksi dilakukan pada generasi lanjut (Mahalingam et al., 2011; Sulistyowati et al., 2015 ).

Analisis kurtosis terhadap arsitektur malai padi populasi zuriat persilangan IPB 3S/IPB160-F-36 dan IPB160-F-36/IPB 5R menunjukkan hampir seluruh karakter arsitektur malai dikendalikan oleh banyak gen (polygenic) kecuali karakter panjang cabang primer dan jumlah gabah per cabang primer pada populasi zuriat IPB 3S/IPB160F-36. Karakter arsitektur malai yang merupakan karakter kuantitatif umumnya dikendalikan oleh banyak gen. Jumlah gen yang mengendalikan karakter akan mempengaruhi tingkat kesulitan program pemuliaan (Lestari et al., 2015; Luo et al., 2013; Roy, 2000).

\section{Ragam dan Heritabilitas}

Keragaman suatu populasi tanaman memiliki arti yang sangat penting bagi pemulia tanaman. Besar kecilnya keragaman sangat menentukan keberhasilan seleksi. Seleksi merupakan dasar dari seluruh kegiatan pemuliaan untuk mendapatkan varietas unggul baru. Semakin tinggi keragaman genetik suatu populasi menandakan semakin besar peluang untuk mendapatkan karakter-karakter yang dikehendaki. Nilai duga ragam dan heritabilitas zuriat persilangan IPB 3S/IPB160-F-36 dan IPB160-F-36/IPB 5R disajikan dalam Tabel 2.

Keragaman genetik diantara karakter-karakter yang diuji memiliki peran penting dalam pemuliaan untuk memilih sifat-sifat yang diinginkan (Mazid et al., 2013; Seyoum et al., 2012). Proses seleksi untuk setiap karakter akan lebih efektif apabila karakter tersebut memiliki nilai keragaman fenotipe dan genetik yang tinggi. Semakin besar keragaman genetik suatu populasi semakin besar peluang untuk mendapatkan karakter yang dikehendaki (Singh et al., 2011). Keragaman yang tinggi pada karakter arsitektur malai yang diuji membuktikan bahwa individu populasi persilangan memiliki latar belakang genetik yang berbeda. Nilai tengah tetua dan distribusi karakter arsitektur malai pada dua populasi F2 disajikan dalam Gambar 1.

Heritabilitas adalah perbandingan antara besaran ragam genetik dengan besaran total ragam fenotip dari suatu karakter. Hubungan ini menggambarkan seberapa jauh fenotipe yang tampak merupakan refleksi dari genotipe (Syukur et al., 2015). Hasil pendugaan nilai heritabilitas terhadap dua populasi persilangan menunjukkan hasil yang berbeda yaitu tinggi sampai sedang. Karakter panjang cabang primer dan jumlah gabah per cabang primer menunjukkan nilai heritabilitas yang tinggi pada dua populasi yang diuji. Karakter panjang malai, jumlah cabang primer dan kerapatan gabah menunjukkan perubahan kriteria yaitu tinggi pada salah satu populasi dan sedang pada populasi lainnya. Hal ini serupa dengan laporan Lestari et al. (2015) dan Bitew (2016) bahwa karakter panjang malai memiliki nilai heritabilitas sedang. Namun, Singh et al. (2011), Devic et al. (2012) dan Akhmadi et al. (2017) melaporkan nilai heritabilitas tinggi pada karakter panjang malai tanaman padi. Nilai heritabilitas tinggi memiliki arti penting dalam efektivitas seleksi. Karakter-karakter dengan nilai heritabilitas tinggi seleksi akan berlangsung efektif dan seleksi dapat dilakukan pada generasi awal karena pengaruh lingkungan yang kecil dalam penampilan karakter tersebut (Akinwale et al., 2011). Nilai duga heritabilitas penting diketahui karena dapat digunakan untuk menentukan karakter mana yang digunakan sebagai penentu seleksi.

\section{Kemajuan Genetik}

Kemajuan genetik merupakan suatu nilai kuantitatif dari respon populasi atas adanya seleksi pada populasi tersebut. Teknik seleksi dan besaran intensitas seleksi yang

Tabel 2. Parameter genetik arsitektur malai padi zuriat persilangan IPB 3S/IPB160-F-36 dan IPB160-F-36/IPB 5R

\begin{tabular}{|c|c|c|c|c|c|c|}
\hline \multirow{2}{*}{ Karakter } & \multirow{2}{*}{$\sigma^{2} \mathrm{p}$} & \multirow{2}{*}{$\sigma^{2} \mathrm{e}$} & \multirow{2}{*}{$\sigma^{2} \mathrm{~g}$} & \multirow{2}{*}{ KKG } & \multicolumn{2}{|c|}{$\mathrm{h}^{2} \mathrm{bs}$} \\
\hline & & & & & Nilai & Kriteria \\
\hline \multicolumn{7}{|c|}{ Zuriat persilangan IPB 3S/IPB160-F-36 } \\
\hline Panjang malai & 2.88 & 0.65 & 2.23 & 4.99 & 0.77 & Tinggi \\
\hline Jumlah cabang primer & 1.11 & 0.57 & 0.54 & 5.63 & 0.49 & Sedang \\
\hline Panjang cabang primer & 1.12 & 0.40 & 0.72 & 5.94 & 0.64 & Tinggi \\
\hline Jumlah gabah/cabang primer & 8.40 & 2.98 & 5.41 & 11.00 & 0.64 & Tinggi \\
\hline Kerapatan gabah & 0.02 & 0.01 & 0.01 & 7.03 & 0.43 & Sedang \\
\hline \multicolumn{7}{|c|}{ Zuriat persilangan IPB160-F-36/IPB 5R } \\
\hline Panjang malai & 2.36 & 1.61 & 0.75 & 2.99 & 0.32 & Sedang \\
\hline Jumlah cabang primer & 1.44 & 0.49 & 0.94 & 7.34 & 0.66 & Tinggi \\
\hline Panjang cabang primer & 1.20 & 0.46 & 0.74 & 6.40 & 0.62 & Tinggi \\
\hline Jumlah gabah/cabang primer & 9.87 & 1.53 & 8.35 & 12.8 & 0.85 & Tinggi \\
\hline Kerapatan gabah & 0.02 & 0.01 & 0.01 & 7.63 & 0.61 & Tinggi \\
\hline
\end{tabular}

Keterangan: $\sigma^{2} \mathrm{p}=$ ragam fenotip, $\sigma^{2} \mathrm{e}=$ ragam lingkungan, $\sigma^{2} \mathrm{~g}=$ ragam genetik, $\mathrm{KKG}=$ koefisien keragaman genetik, $\mathrm{h}^{2} \mathrm{bs}=$ heritabilitas arti luas 
Populasi IPB 3S/IPB160-F-36

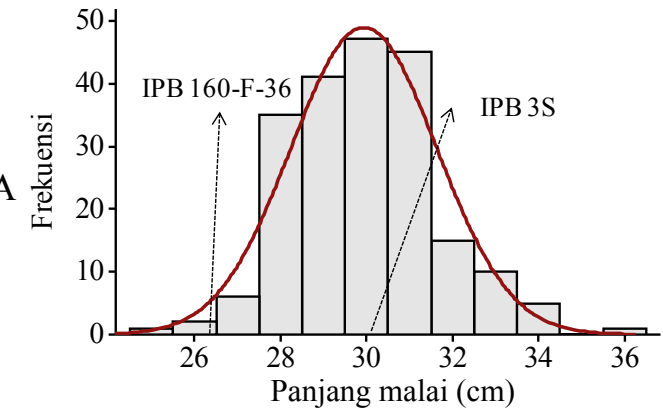

B

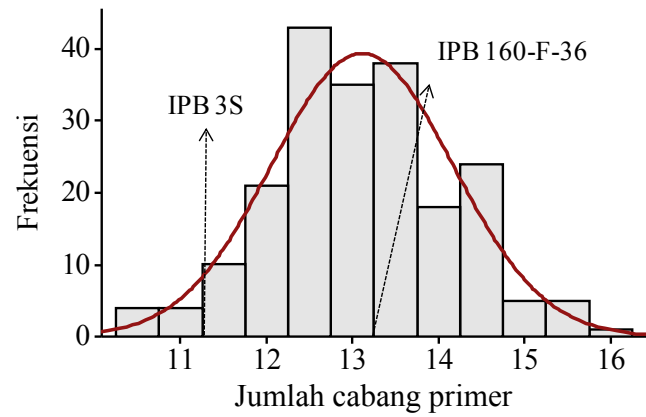

Populasi IPB160-F-36/IPB 5R
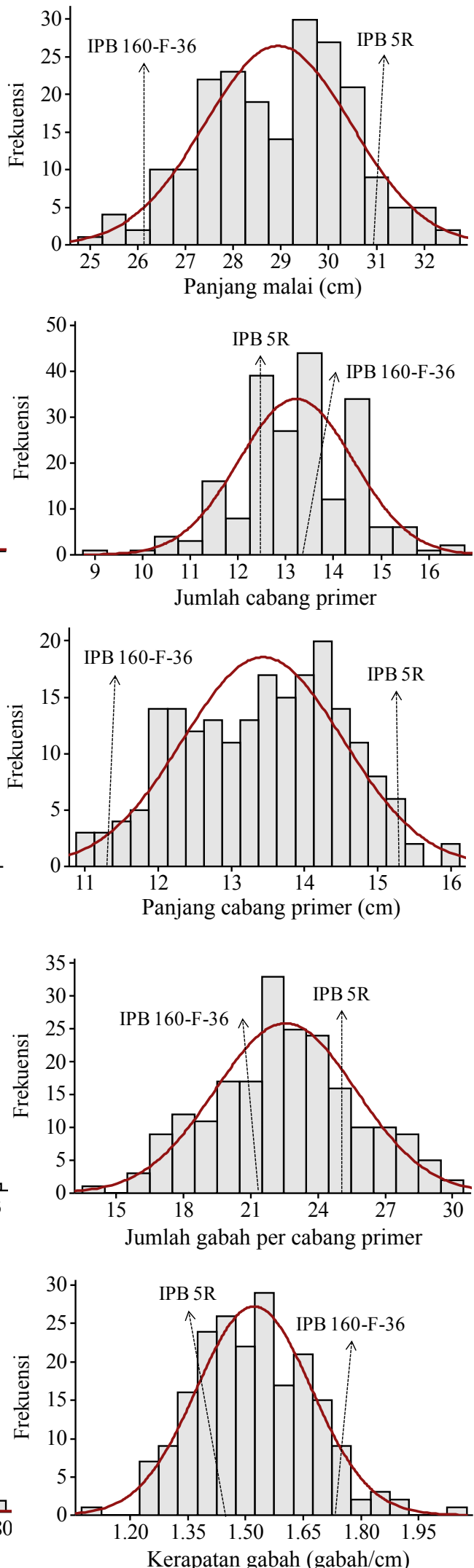

Gambar 1. Nilai tengah tetua dan distribusi karakter arsitektur malai pada dua populasi F2. (A) panjang malai, (B) jumlah cabang primer,

(C) panjang cabang primer, (D) jumlah gabah per cabang primer, dan (E) kerapatan gabah 
dilakukan menentukan besarnya kemajuan genetik, selain itu kemajuan genetik juga berhubungan erat dengan besarnya dugaan nilai heritabilitas (Muslimin et al., 2013). Kemajuan genetik dapat dijadikan petunjuk dalam penentuan kegiatan seleksi. Bila nilai kemajuan genetik suatu karakter tinggi berarti besar peluang untuk dilakukannya perbaikan karakter tersebut melalui seleksi. Sebaliknya jika nilai kemajuan genetik rendah, maka kegiatan seleksi pada karakter tersebut dapat dilakukan pada satu kali generasi untuk membentuk populasi yang seragam atau kegiatan seleksi dapat dihentikan karena perbaikan yang akan dicapai relatif rendah (Muliarta, 2010). Nilai duga kemajuan genetik zuriat persilangan IPB 3S/IPB160-F-36 dan IPB160-F-36/IPB 5R disajikan pada Tabel 3.

Seleksi menggunakan satu karakter secara umum dapat dilakukan dengan mudah. Akan tetapi, penggunaan satu karakter sering kali harus mengorbankan karakter lain yang juga berperan penting terhadap komponen hasil suatu tanaman. Hal ini terjadi apabila karakter-karakter tersebut dikendalikan oleh gen yang sama atau gen-gen dalam keadaan terpaut (Syukur et al., 2015). Kekurangan seleksi per karakter dapat diatasi menggunakan seleksi secara simultan dimana seleksi dilakukan terhadap beberapa karakter sekaligus. Seleksi secara simultan pada populasi zuriat persilangan IPB 3S/IPB160-F-36 menunjukkan diperolehnya group individu yang memiliki kemajuan genetik tinggi pada karakter jumlah gabah per cabang primer dan panjang cabang primer. Seleksi pada populasi IPB160-F-36/IPB 5R menunjukkan terpilihnya individuindividu superior yang memiliki kemajuan genetik tinggi pada karakter jumlah gabah per cabang primer dan kerapatan gabah.

Nilai duga kemajuan genetik yang tinggi didukung oleh nilai heritabilitas tinggi yang mengindikasikan karakter tersebut dapat dijadikan target seleksi karena ditentukan oleh faktor genetik sehingga seleksi akan efektif dan efisien (Nwangburuka dan Denton, 2012; Ogunniyan dan Olakojo, 2014). Dalam penelitian ini, seluruh karakter arsitektur malai populasi zuriat persilangan IPB 3S/IPB160-F-36 memiliki nilai heritabilitas dan kemajuan genetik sedang sampai tinggi sehingga dapat dijadikan target seleksi menggunakan metode seleksi tunggal. Jika dilakukan secara simultan, semua karakter arsitektur malai dapat dijadikan target seleksi karena memiliki nilai kemajuan genetik yang positif. Namun, karakter jumlah gabah per cabang primer dan panjang cabang primer merupakan karakter terbaik. Berbeda dengan populasi zuriat persilangan IPB 3S/IPB160-F-36, pada populasi persilangan IPB160-F36/IPB 5R karakter panjang malai tidak dapat dijadikan target seleksi karena meskipun memiliki nilai heritabilitas sedang namun nilai kemajuan genetik rendah. Hal ini sesuai dengan laporan Seyoum et al. (2012). Jika dilakukan seleksi secara simultan maka karakter jumlah gabah per cabang primer dan kerapatan gabah merupakan karakter terbaik untuk dijadikan target seleksi. Meskipun seleksi dilakukan secara simultan, karakter panjang malai memiliki nilai kemajuan yang rendah pada kedua metode seleksi. Seleksi per karakter dan simultan memberikan pilihan bagi pemulia untuk mempermudah proses seleksi karakter-karakter yang dikehendaki.

Tabel 3. Kemajuan genetik arsitektur malai padi per karakter dan simultan zuriat persilangan IPB 3S/IPB160-F-36

\begin{tabular}{lccccc}
\hline \multirow{2}{*}{ Karakter } & \multicolumn{3}{c}{ Seleksi per karakter } & \multicolumn{2}{c}{ Seleksi simultan $(\mathrm{n}=11)$} \\
\cline { 2 - 6 } & $\mathrm{n}$ & $\mathrm{G}$ & $\mathrm{G}(\%)$ & $\mathrm{G}$ & $\mathrm{G}(\%)$ \\
\hline \multirow{2}{*}{ Panjang malai } & \multicolumn{2}{c}{ Zuriat persilangan IPB 3S/IPB160-F-36 } & & 5.83 \\
Jumlah cabang primer & 11 & 2.95 & 9.84 & 1.74 & 3.09 \\
Panjang cabang primer & 11 & 1.06 & 8.08 & 0.41 & 8.95 \\
Jumlah gabah/cabang primer & 10 & 1.59 & 11.19 & 1.28 & 16.47 \\
Kerapatan gabah & 10 & 4.61 & 21.83 & 3.48 & 5.25 \\
& 12 & 0.14 & 10.46 & 0.07 & -0.18 \\
Panjang malai & Zuriat persilangan IPB160-F-36/IPB 5R & 3.69 & -0.05 & 0.01 \\
Jumlah cabang primer & 5 & 1.07 & 12.51 & 0.00 & 5.49 \\
Panjang cabang primer & 9 & 1.65 & 10.29 & 0.74 & 23.94 \\
Jumlah gabah/cabang primer & 5 & 1.38 & 24.08 & 5.40 & 11.97 \\
Kerapatan gabah & 9 & 5.43 & 14.33 & 0.18 & \\
\hline
\end{tabular}

Keterangan: $\mathrm{G}=$ kemajuan genetik, $\mathrm{G}(\%)=$ kemajuan genetik dalam persen, $\mathrm{n}=$ jumlah individu terseleksi

\section{KESIMPULAN}

Terdapat aksi gen aditif, dominan, epistatis komplementer dan epistatis aditif yang mengendalikan karakter arsitektur malai populasi zuriat persilangan IPB 3S/ IPB160-F-36 dan IPB160-F-36/IPB 5R. Karakter arsitektur malai sebagian besar dikendalikan oleh banyak gen kecuali pada karakter panjang cabang primer dan jumlah gabah per 
cabang primer pada populasi zuriat persilangan IPB $3 \mathrm{~S} /$ IPB160-F-36. Terdapat keragaman karakter arsitektur malai dari dua populasi yang diuji. Heritabilitas arti luas karakter arsitektur malai tergolong sedang sampai tinggi. Seleksi meningkatkan nilai tengah karakter arsitektur malai baik seleksi per karakter maupun simultan.

\section{UCAPAN TERIMA KASIH}

Penelitian ini didanai oleh Kementrian Riset, Teknologi dan Pendidikan Tinggi tahun 2016 dan 2017, Nomor: 079/SP2H/LT/DRPM/II/2016 dan Nomor: 011/SP2H/LT/ DRPM/IV/2017 an. Dr. Ir. Hajrial Aswidinnoor, M.Sc.

\section{DAFTAR PUSTAKA}

Abdullah,B., S. Tjokrowidjojo, Sularjo. 2008. Perkembangan dan prospek perakitan padi tipe baru di Indonesia. J. Litbang Pertanian 1:1-27.

Akhmadi, G., B.S. Purwooko, I.S. Dewi, D. Wirnas. 2017. Pemilihan karakter agronomi untuk seleksi pada galur-galur padi dihaploid hasil kultur antera. J. Agron. Indonesia 45:1-8.

Adriani, D.E., M. Dingkuhn, A. Dardou, H. Adam, D. Luquet, T. Lafarge. 2016. Rice panicle plasticity in near isogenic lines carrying a QTL for larger panicle is genotype and environment dependent. Rice 9:115 .

Akinwale, M.G., G. Gregorio, F. Nwilane, B.O., Akinyele, S. A. Ogunbayo, A. C. Odiyi. 2011. Heritability and correlation coefficient analysis for yield and its components in rice (Oryza sativa L.). African J. Plant Sci. 5:207-212.

Anyanwu, C.P., L.U. Obi. 2015. Genetic effects on panicle traits of crossbred rainfed rice cultivars using generation mean analysis. J. Plant Breed. Crop Sci. 7:134-142.

Bitew, J.M. 2016. Estimation of genetic parameters, heritability and genetic advance for yield related traits in upland rice (Oryza sativa L. and Oryza glaberrima Steud) genotypes in Northwestern Ethiopia. Word Scientific News 47:340-350.

Devic, B., G.M. Lal, C.M. Singh, P. Yadav. 2012. Genetic architecture, interrelationship and path analysis for yield improvement in exotic rice (Oryza sativa L.). Intl. J. Agric. Env. Biotech. 5:387-392.

Futsuhara, Y., S.A. Kondo, H. Kitano. 1980. Genetical studies on dense and lax panicle in rice I. Character expression and mode of lax panicle rice. Japan. J. Breed. 29:151-158.
Huang, X.H., X.H. Wei, T. Sang, Q. Zhao, Q. Feng, Y. Zhao, C. Li, C.R. Zhu, T. Lu, Z. Zhang, M. Li, D.L. Fan, Y.L. Guo, A.H. Wang, L. Wang, L.W. Deng, W.J. Li, Y.Q. Lu, Q.J. Weng, K.Y. Liu, T. Huang, T.Y. Zhou, Y.F. Jing, W. Li, Z. Lin, E.S. Buckler, Q. Qian, Q.F. Zhang, J.Y. Li, B. Han 2010. Genome-wide association studies of 14 agronomic traits in rice landraces. Nat Genet. 42:961-967.

Ikeda, M., Y. Hirose, T. Takashi, Y. Shibata, T. Yamamura, T. Komura, K. Doi, M. Ashikari, M. Matsuoka, H. Kitano. 2010. Analysis of rice panicle traits and detection of QTLs using an image analyzing method. Breed. Sci. 60:55-64.

Ikeda, M., K. Miura, K. Aya, H. Kitano, M. Matsuoka. 2013. Genes offering the potential for designing yield-related traits in rice. Curr. Opinion Plant Biol. 16:213-220.

Jambormias, E. 2014. Analisis genetik dan segregasi transgresif berbasis informasi kekerabatan untuk potensi hasil dan panen serempak kacang hijau. Disertasi. Institut Pertanian Bogor. Bogor.

Jayaramachandran, M., N. Kumaravadivel, S. Eapen, G. Kandasamy. 2010. Gene action for yield attributing characters in segregating generation (M2) of sorghum (Sorghum bicolor L.). Elec. J. Plant Breeding. 1:802808.

Lestari, A.P., Suwarno, Trikoesoemaningtyas, D. Sopandie, H. Aswidinnoor. 2015. Panicle length and weight performance of F3 population from local and introduction hybridization of rice varieties. Hayati J. Biosci. 22:87-92.

Luo, X., S.H. Ji, P.R. Yuan, H. S. Lee, D. M. Kim, S. Balkunde, J.W. Kang, S.N. Ahn. 2013. QTL mapping reveals a tight linkage between QTLs for grain weight and panicle spikelet number in rice. Rice 6:1-10.

Mahalingam, A., S. Robin, K. Mohanasundaram, R. Pushpam. 2011. Studies on genetic architecture of biparental progenies for important yield attributes in rice (Oryza sativa L.). J. Plant Breed. Crop Sci. 3:296-301.

Mahmood, T. M., F. L. Turner, Stoddard, M. A. Javed. 2004. Genetic analysis of quantitative traits in rice (Oryza sativa L.) exposed to salinity. Australian J. Agric. Res. 55:1173-1181.

Mazid, M.S., M.Y. Rafii, M.M. Hanafi, H.A. Rahim, M. Shabanimofrad, M.A. Latif. 2013. Agromorphological characterization and assessment of variability, heritability, genetic advance and divergence in bacterial blight resistant rice genotypes. South African J. Botany 86:15-22. 
Muliarta, A. 2010. Uji keseragaman, heritabilitas, dan kemajuan genetik galur padi beras merah hasil seleksi silang balik di lingkungan gogo. Crop Agro. 3:10-17.

Muslimin, I., A. Sofyan, S. Islam. 2013. Genetic parameter estimates in a clonal test of teak (Tectona grandis L. f) at 5.5 years old in South Sumatera. J. Pemuliaan Tanaman Hutan 7:97-106.

Nwangburuka, C.C., O.A. Denton. 2012. Heritability, character association and genetic advance in six agronomic and yield related character in leaf Chorchorus olitorius. Int. J. Agric. Res. 7:367-375.

Ogunniyan, D.J., S.A. Olakojo. 2014. Genetic variation, heritability, genetic advance and agronomic character association of yellow elite inbred lines of maize (Zea mays L.). Nigerian J. Genetics 28:24-28.

Poehlman, J.M., D.A. Sleper. 1996. Breeding Field Crops. $4^{\text {th }}$ Edition. Iowa, Iowa State University Press, USA.

Prabakaran, A., K. Pramasivam, T. Rajesh, D. Rajanrajan. 2010. Molecular characterization of rice landrace using SSR markers. Electronic J. Plant Breed. 1:512516.

Roy, D. 2000. Plant Breeding: Analysis and Exploitation of Variation. New Delhi: Narosa, India.

Saleem, M.Y., B.M. Atta, A.A. Cheema, M.A. Haq. 2005. Genetics of panicle-related traits of agronomic importance in rice through triple test cross analysis. Spanish J. Agric. Res. 3:402-409.
Samak, N.R.A., S. Hittalmani, N. Shashidar, H. Biradar. 2011. Exploratory studies on genetic variability and genetic control for protein and micronutrient content in F4 and F5 generation of rice (Oryza sativa L.). Asian J. Plant Sci. 10:376-379.

Seyoum, M., S. Alamerew, K. Bantte. 2012. Genetic variability, heritability, correlation coefficient and path analysis for yield and yield related traits in upland rice (O. sativa L.). J. Plant Sci. 7:13-22.

Singh, S.K., M.C. Singh, G.M. Lal. 2011. Assessment of genetic variability for yield and its component characters in rice (Oryza sativa L.). Res. Plant Bio. 1:73-76.

Syukur, M., S. Sujiprihati, R. Yunianti. 2015. Teknik Pemuliaan Tanaman. Edisi Revisi. Penebar Swadaya, Jakarta.

Stansfield, W.D. 1991. Schaum's Outline of Theory and Problem of Genetics. The McGraw-Hill Companies, New York, USA.

Sulistyowati, Y., Trikoesoemaningtyas, D. Sopandie, S. W. Ardie, S. Nugroho. 2015. Estimation of genetic parameters and gene actions of sorghum (Sorghum bicolor (L.) Moench) tolerance to low P condition. Int. J. Agro. Agri. Res. 7:38-46.

Zhang, Y.F., M. Yu-yin, C.X. Zong, Z. Jie, C. Tian-xiao, L. Qian-qian, P. Xue-biao, Z. Shi-min. 2015. Genomewide association studies reveal new genetic targets for five panicle traits of international rice varieties. Rice Science 22:217-226. 